How to cite this article: Ribeiro, A. S., \& Ribeiro, M. C. (2018). A Past that Will Not Go Away. The Colonial War in Portuguese Postmemory. Lusotopie, 17(2), 277-300. https://doi.org/10.1163/17683084-12341722

\title{
A Past that Will Not Go Away. The Colonial War in Portuguese Postmemory
}

\section{António Sousa Ribeiro}

Professor catedrático do Departamento de Línguas, Literaturas e Culturas (Estudos Germanísticos) da Faculdade de Letras da Universidade de Coimbra e investigador no Centro de Estudos Sociais, Portugal

asr@ces.uc.pt

\section{Margarida Calafate Ribeiro}

Investigadora-coordenadora no Centro de Estudos Sociais da Universidade de Coimbra, Portugal

\section{margaridascr@gmail.com}

\section{Abstract}

The article discusses the concept of postmemory, demonstrating its productivity through an analysis of the memorialization of the Colonial War in the contemporary Portuguese context. Drawing on the results of two research projects carried out at the Centre for Social Studies of the University of Coimbra, different aspects of the production of postmemory by members of the second generation are presented, with particular, but not exclusive, emphasis on the domain of the arts.

\section{Keywords}

colonial war; memory; postmemory; second generation; trauma 


\section{Un passé qui ne veut pas disparaître. La Guerre coloniale dans la post- mémoire portugaise}

\section{Résumé}

L'article discute le concept de post-mémoire, tout en démontrant son opérationnalité au moyen d'une analyse de la production de la mémoire de la Guerre Coloniale dans le contexte portugais contemporain. En se fondant sur les résultats de deux projets de recherche conduits au Centre d'Études Sociales de l'Université de Coimbra, il présente divers aspects de la production de postmémoire par des membres de la deuxième génération, tout en mettant en particulier l'accent, mais pas de manière exclusive, sur le domaine des arts.

\section{Mots-clefs}

deuxième génération; guerre coloniale; mémoire; post-mémoire; trauma

\section{Um passado que não passa. A Guerra Colonial na Pós-Memória Portuguesa}

\section{Resumo}

O artigo discute o conceito de pós-memória, demonstrando a sua produtividade através de uma análise da memorialização da Guerra Colonial no contexto português contemporâneo. Com base nos resultados de dois projetos de investigação realizados no Centro de Estudos Sociais da Universidade de Coimbra, apresentam-se diferentes aspetos da produção de pós-memória por parte de membros da segunda geração, focando, em particular, mas não em exclusivo, o universo das artes.

\section{Palavras-chave}

guerra colonial; memória; pós-memória; segunda geração; trauma 
What shall I do with this bastard, this negro who keeps falling and falling to the ground, his belly button torn apart, inside me, what shall I do with this negro who will for ever be falling to the ground, every second, with his belly button torn apart, inside me ...

António Lobo Antunes, Fado Alexandrino ${ }^{1}$

It is no accident that the concern with processes of remembrance leading, in the long run, to the current boom in memory studies is indissolubly tied to the catastrophic history of the 20th century. Maurice Halbwachs started writing and publishing his ground-breaking work on collective memory and the social framework of memory in the 1920s (Halbwachs 1994 [1925], 1997 [1950]); on the other hand, with the publication, in 1929, of Témoins, his long reflection on the memory of the First World War as seen through the eyes of the participants, Jean Norton Cru, as is unanimously recognized, may be considered to have inaugurated the paradigm of testimony as a central location of the work of remembrance (Cru 1929). In the wake of the Second World War and the Holocaust, that paradigm would acquire such prominence that Annette Wieviorka felt entitled to characterize our era as the 'era of the witness' (Wieviorka 2002). In the process, the conceptual framework developed by Holocaust theory and Holocaust studies came to offer a paradigmatic reference apt to inform the overall reflection on phenomena of extreme violence in modernity; studies on violence and on traumatic memory now mostly rely on that framework and demonstrate its productivity on a current basis. ${ }^{2}$

Among concepts developed in the last few decades within the framework of the Holocaust paradigm, the notion of postmemory ranks as one of the most influential. As is well known, this concept was originally put forward by Marianne Hirsch in her book Family Frames (Hirsch 1997). In Hirsch's definition,

$\overline{1}$ Whenever not otherwise indicated, all translations are by the authors. "O que faço ao sacana deste preto que não acaba de cair, de umbigo roto, no interior de mim, o que farei a este preto que cairá para sempre, a cada segundo, de umbigo roto, no interior de mim...." (Antunes 1989: 40).

2 On the Holocaust as a global paradigm, see e.g., Levy \& Sznaider (2002), Dubiel (2003), Ribeiro (2010). 
Postmemory describes the relationship of the second generation to powerful, often traumatic, experiences that preceded their births but that were nevertheless transmitted to them so deeply as to seem to constitute memories in their own right.

Hirsch 2008

"Postmemory" designates a process which had been tackled already in Holocaust research in different ways, e.g. through notions such as the one of a "secondary" witness (see e.g. Dominick LaCapra 1998), a "vicarious" witness (James Edward Young 2000), or an "adoptive" witness (Geoffrey Hartman 2006: 260). However, possibly through its entanglement with the notion of "memory", Hirsch's proposal has gained prominence and currency in a way that has by now firmly established the concept in academic discourse.

In its original formulation, one of the many issues raised by Hirsch's controversial concept had to do with its pointing to a process of transmission which was located primarily in the private, mainly the family sphere. In her critique of Hirsch, Beatriz Sarlo lays a heavy stress on the private, essentially apolitical resonance of the notion. ${ }^{3}$ As we argue, however, Hirsch's concept can be reelaborated in ways that project it onto the public sphere and are inseparable from a notion of political commitment.

The question could thus be raised of whether a public postmemory is possible at all and, concomitantly, whether such a public postmemory can be truly transgenerational, in a sense that would extend beyond the notion of a "second generation". In more recent formulations, the scope of the concept has been consistently enlarged in this direction. This is a vital move, if the concept is to be made fully operative, since it allows to locate the work of postmemory within a societal context where any notion of a linear transmission of memory has to be forsaken to the benefit of a more sophisticated notion. Thus, a sense of recollection gives way to a sense of investment, negotiation and reconstruction across the unbridgeable gap that separates the real actor - whether victim or perpetrator - from those who, not having participated, are willing to take the option of merging deeply enough into the experience of others.

Central keywords for such a process are recognition and compassion, compassion being understood in this framework not as a passive "feeling" of empathy, but as a performative gesture, a cognitive action through which the experience, notably the experience of suffering of others may be incorporated into our own framework of perception. Under this light, the "post" in "postmemory" comes to signal a gap, a reflective moment, it is a mark of distance,

3 See the chapter "Pós-memória, reconstituições", in Beatriz Sarlo (2007). 
pointing at something that is never simply "already there", but is the product of a particular kind of labour through which the contemporary relevance of the past can be enacted. Thus, postmemory literally represents an act of translation, if one understands translation as being an epistemological model for strategies of relating to and incorporating discourses and experiences that belong to a framework of reference that is by definition strange and inassimilable.

While the concept of "postmemory" has found its way into a few academic dissertations and the word certainly circulates in the Portuguese public sphere, it cannot be said to enjoy widespread usage in a Portuguese context. It is, however, a notion that proves to be particularly relevant for an understanding of contemporary Portuguese society in its relation to the colonial past and, in particular, to the great catastrophic event of twentieth-century Portuguese history, the Colonial War. As is well known, Portugal conducted between 1961 and 1974 in Angola, Mozambique and Guinea-Bissau a protracted Colonial War. The war was never recognized as such by the Salazar regime: it was consistently underplayed as a conspiracy by Communist-supported international "terrorism" against Portugal and, as such, it was presented as simply a large-scale police operation, notwithstanding the huge effort demanded of the national budget and the hundreds of thousands of young men forcibly enrolled in the colonial army. Under the prevailing conditions of censorship, perception of the true extent and meaning of the war could successfully remain hidden from the general public and be perceived as some kind of distant, external event. The fact that the overthrow of the Caetano dictatorship and the establishment of a democratic regime in the wake of the so-called Carnation Revolution was the doing of members of the colonial army, the young officers rallied in the Movimento das Forças Armadas (MFA), is a key factor in understanding why Portugal's long colonial history and the murderous thirteen years of war against the liberation movements were never the subject of widespread public debate. Not the least, the sheer fact that many former combatants live in what, following Primo Levi, could be named a "grey zone" between the self-stylization as a victim (e.g. of post-traumatic stress disorder, a condition affecting a high percentage of former members of the military) and the fact of having belonged to a colonial army and, in several cases, of having been a perpetrator, has contributed to a great extent to the prevalence of a veil of silence. Thus, while hardly any Portuguese family remained untouched, by having at least one of its members taking part in the war, and while many families, to this day, suffer from the consequences of the conflict, the great weight carried by private memories is in no way counterbalanced by the existence of a public memory that might be said to provide Portuguese society with an ample awareness of the extent of violence implied by the war, let alone of the import of Portugal's long colonial 
history, as testified e.g. by the prevalence of what might be called a racist unconscious among large sectors of the population.

The often quite large time gap between violent, traumatic events and their surfacing in general public awareness and in public discussion is a well-known phenomenon that is well documented in the case of the Holocaust, but also in relation to many other events, like the Algerian War. ${ }^{4}$ In the Portuguese case, it would seem that, more than forty years after the final demise of Portuguese colonialism, the silence is being broken. This is not to say, of course, that it had not been broken before, particularly concerning the thematization of the Colonial War in literature and the arts - from the poetry of Fernando Assis Pacheco or Manuel Alegre to the novels of António Lobo Antunes or Lídia Jorge, from the films of João Botelho or António Pedro Vasconcelos to the engravings of Bartolomeu Cid dos Santos, the photographs and watercolors of João Botelho or the paintings and sculptures of João Cutileiro or Clara Meneres. ${ }^{5}$ Above all in recent years the conditions for the production of testimony have become generally more favourable. ${ }^{6}$ However, the major shift has to do with the increasingly forceful emergence of the work of postmemory, well beyond the confines of the memory bearers, of those having had first-hand experience of events. Some such "memory bearers", as we were able to witness personally on several public occasions, even resent the subject of the war being taken over by young people with no direct experience of suffering. Others, to the contrary, manifest a clear-cut conscience of the significance of the postmemorial agency of younger generations, very much in the sense of the appeal contained in a magazine chronicle published by António Lobo Antunes in 2002:

This returns like vomit - I have to talk about this. And you have to listen, because I can still hear it. [...] Even if I write this badly because I am writing with the blood of my dead. I cannot forget. I am not able to forget. I, no. $07890263 \mathrm{ORH}+$, cannot forget. [...] I was there. I saw it. [...] If I am blown up with the mine-sweeping truck, at least let the echo of my cry remain.

4 For the latter case, one that presents striking similarities with the Portuguese one, see Benjamin Stora (1999). For a different, but in some sections equally interesting approach, see Blanchard et al. (2005).

5 In this regard, see in particular Margarida Calafate Ribeiro (2004).

6 A particularly important landmark is Joaquim Furtado's outstanding documentary $A$ Guerra (2007), shown on Portuguese television and giving voice to a number of participants from all sides - albeit, in most cases, participants of a high or at least a certain level of prominence, which leaves aside the testimony of the common combatant. 
You, who remain behind, complete this chronicle. $07890263 \mathrm{ORH}+{ }^{7}$

You, who remain behind, those who might be able to capture the "echo of my scream", are the children of former combatants, no doubt, but more generally, they are members of subsequent generations who, quite often with no family connection to the experience of war, have chosen to engage in postmemorial work in the sense outlined in our introduction. The question raised by Antunes' pronouncement leads to several problems related to the possibility of providing testimony, of transmitting testimony and, in the end, to the very conditions of the production and reception of testimony. In other words: would the parents be able to tell the history of the war? And which history would be told? Would the children and, in a wider sense, Portuguese society at large be willing and interested in listening? Would the children be willing to accept such a legacy and to take it over as a kind of "transgenerational phantom" in the sense of Nicolas Abraham e Maria Torok ${ }^{8}$ I.e. would the children be willing to listen and to deal with received testimony with the degree of compassion necessary for the inscription of that testimony in their own identity, making it a part of themselves? This is the process through which subsequent generations may assume the identity of a "child of the Holocaust", "child of a Nazi", "child of a missing person", "child of a political prisoner", "child of the Colonial p". The assumption of such an identity is entirely contingent upon active processes of remembrance in the framework of which private, mostly family memories may be projected onto the public sphere and thus work against the veil of silence

7 "Isso regressa como um vómito e tenho de falar nisso. Vocês têm de ouvir, porque eu continuo a ouvir. [...] Mesmo que eu escreva isto mal porque estou a escrever com o sangue dos meus mortos. Não posso esquecer. Não consigo esquecer. Eu, o $078902630 \mathrm{RH}+$, não consigo esquecer. [...] Eu estive lá. Eu vi. [...] Se eu saltar com o rebenta-minas que fique, ao menos, o eco do meu grito. Completem esta crónica, vocês, os que cá ficam. 078902630RH+". António Lobo Antunes (2006). In one of his great essays, Imre Kertész expresses very much the same perception, while explicitly stressing the indispensable agency of the subsequent generations: "But to whom will it [Auschwitz] belong? Obviously, to the next generation, and to the one after that - as long as they continue to lay claim to it, of course" (Kertész 2001: 267). Our italics.

8 The notion of a "transgenerational phantom" was elaborated for the first time in "Notes on the Phantom: A Complement to Freud's Metapsychology", an article published in 1975. It was later further developed in Story of Fear: The Symptoms of Phobia - the Return of the Repressed or the Return of the Phantom and The Phantom of Hamlet or The Sixth Act, preceded by The Intermission of Truth. All three articles have been included by Nicholas Rand (1994). For further information, cf. Inês Rodrigues (2017). 
posttraumatic societies tend to impose on those societies' entanglement with political violence.

\section{Fragments of a Discourse of Inheritance ${ }^{9}$}

War ... it is those things that come by and by, they do not follow a linear pattern. ${ }^{10}$

War was that handful of photos, he with the boa constrictor, he on top of the crocodile, he with his gun over one shoulder, basically. And always the same stories. ${ }^{11}$

I am the daughter of a former Marine who was deployed overseas for several periods. I have the feeling that I was in a war I have never experienced. ${ }^{12}$

I always remember, from my childhood on, from time to time, it occurred like a crisis, at specific moments ... Many, incidentally, many moments in the course of my life, often, at night, we had to take him to the hospital. Then, they gave him a shot in the vein, probably some tranquilizer, he would stabilize and become calm. There was ... It was always like this, as far as I remember. To have a bad sleep on many nights. When he could sleep at all ... When he sleeps better, it is only with the help of pills. $^{13}$

My father always thinks, up to this day, that my mother does not understand what he went through. My mother always thinks he does not understand what she went through. And I understand both. But I cannot get them to truly discuss this in a peaceful way. Well, for my father that

9 All testimonies not published remain anonymous, except the ones from the artists. 10 "A guerra ... são coisas que vêm assim aos poucos, não têm assim um seguimento". 11 "A guerra era essa meia dúzia de fotografias que era ele com a jibóia, e ele em cima do crocodilo, e ele com a arma a tiracolo, basicamente. E sempre as mesmas histórias".

12 "Sou filha de um ex-fuzileiro especial que efetuou várias comissões ao Ultramar. Sinto que estive numa guerra que nunca vivi".

13 "Sempre me lembra, da minha infância até agora, de vez em quando, era por crises, por momentos ... Muitos, por acaso, muitos momentos ao longo da minha vida, muitas vezes de noite, tínhamos que ir com ele para o hospital. Depois davam-lhe uma injeção na veia, devia ser um calmante, ele então estabilizava e acalmava. Havia ... Que eu me lembre foi sempre assim. Dormir mal muitas noites. E quando dormia ... Quando dorme melhor, só através de medicamentos". 
was his experience and, thus, no one can understand. I understand both to a great extent. ${ }^{14}$

My father was not politically active, neither to the left nor to the right. He had been conscripted for the second time. This was the first destabilization within the family. He was little over thirty when he had to go to Guinea and we remained here alone with our mother. When the 25th of April came, my mother was relieved: my brothers would no longer be conscripted. This was a feeling that was very widespread among Portuguese families: families would be torn apart because men would desert so as not to have to go to war; or they fell apart because they went to war and died. ${ }^{15}$

In 2014 I was preparing my first trip to Angola/Congo River/DRC. Among vaccination plans, visa requests and other formalities, I was struck all of a sudden by a kind of paralysis: suddenly, I had lost my will to go to Angola. [...] My father was there during the war, he was a corporal with the mine sweeping company. All that, the war, it must have been a borderline situation [...]. But he did not say much ... In truth, he said nothing. At home there were some bullets and a cutlass. I saw one or the other photo of his battalion. [...] My depart to Angola made me come definitively out of the books and into "reality", I mean, into myself. ${ }^{16}$

14 "O meu pai acha sempre, ainda hoje acha, que a minha mãe não compreende aquilo por aquilo que ele passou. A minha mãe acha sempre que ele não compreende aquilo por que ela passou. E eu compreendo os dois. Mas não consigo que eles discutam isto verdadeiramente, de uma forma calma. Pronto, para o meu pai aquela experiência foi a dele, e portanto, ninguém pode compreender. Entendo muito os dois".

15 "O meu pai não tinha qualquer actividade política, nem à esquerda nem à direita. Tinha sido chamado para fazer a tropa pela segunda vez. Isso foi a primeira desestabilização na família. Ele tinha 30 e poucos anos quando teve de ir para a Guiné e nós ficámos cá sozinhos com a nossa mãe. Quando foi o 25 de Abril, a mãe respirou de alívio: os meus irmãos já não seriam mobilizados. Era um sentimento muito presente nas famílias portuguesas: ou as famílias se desfaziam porque os homens fugiam para não ir à tropa; ou se desfaziam porque iam para a guerra e morriam". (Ana Vidigal 2010)

16 "Em 2014 encontrava-me a preparar a minha primeira viagem a Angola/Rio Congo/RDC. Entre planos de vacinação, pedidos de visas e outras formalidades fui de repente atacado por espécie de paralisia: de súbito tinha perdido a vontade de ir a Angola. [...] O meu Pai esteve lá na guerra tinha sido um furriel do corpo de 'minas e armadilhas'. Tudo aquilo, a guerra, deve ter sido uma situação limite [...]. Mas ele não disse muito ... Na verdade nada. Havia umas balas lá em casa e uma catana. Vi uma ou outra fotografia do batalhão dele. [...] A minha partida para Angola fez-me definitivamente sair dos livros para a 'realidade', quero dizer para mim mesmo". Hugo Vieira da Silva, May 2016, e-mail to Margarida Calafate Ribeiro. 
My name is Carlos. I was born in 1967. My father went to war when I was ten months old. I do not remember seeing him leave. My father came back from the war when I was almost three. I do not remember seeing him returning. My father's war, the Colonial War, happened before my memory could appropriate things. When my father died, an old man already, I went out to search for his war, and also for mine. ${ }^{17}$

The fragments quoted originated, to a large part, in interviews carried out in the framework of the projects Children of the Colonial Wars: Postmemory and Representations, 2007 to 2010, and Memoirs: Children of Empires and European Postmemoirs, 2015-2020, both hosted at the Centre for Social Studies (CES), University of Coimbra. The former was a pioneering project that studied the impact of the Colonial Wars on Portuguese private, family, collective and cultural memories mainly through the testimony of the children of war veterans and the analysis of cultural and artistic production of the "children of the Colonial Wars", in the form of novels, poetry, film, theatre plays and theatre productions, sculptures, portraits. In methodological terms, the project's approach combined literary criticism, cultural studies, psychiatry, and history, a combination essential to understanding the complexities inherent in (post)colonial memories in Portuguese contemporary societies, marked by "colonial fractures" (Blanchard et al. 2005). "Memoirs: Children of Empires and European Postmemoirs" focuses on the inherited memories of the children and grandchildren of the generation that lived through the dying days of colonialism, the struggles for independence and the decolonization process of the following former colonies of Belgium, France and Portugal - Democratic Republic of Congo (RDC), Algeria, Angola, Mozambique, Guiné-Bissau, Cape Verde and São Tomé e Príncipe. By conducting interviews with the children of both former colonists who returned to Europe after the independence and of members of the colonial armies who took part in the conflicts and wars fought by three European countries to oppose the struggles for independence, and by studying the public and artistic displays of intergenerational memory, "Memoirs" aims to offer new insights into the European postcolonial collective memory under a comparative approach.

17 "Chamo-me Carlos. Nasci em 1967. O meu pai foi para a guerra quando eu tinha dez meses. Não me lembro de o ver partir. O meu pai voltou da guerra quando eu estava prestes a fazer três anos. Não me lembro de o ver chegar. A guerra do meu pai, a Guerra Colonial, aconteceu antes de a minha memória se apropriar das coisas. Quando o meu pai morreu, já velho, fui em busca da guerra dele, e também da minha". Paulo Faria, cover blurb of the book (2016). 
The extensive interviews conducted with Children of the Colonial War from which most of the above fragments were extracted cover a great diversity of situations, including children of men who returned as apparently "normal", children of men suffering from physical disability or psychic disturbances, but also children of deserters, men who took the political option of refusing to go to war. The fragments quoted question us at different levels about what the following generations were able to capture concerning the Colonial War, both in the family and the public spheres; but they also point at some of the contents of memories and recollections, the physical support for its production - conversations, photographs, letters - and some aspect that dislocate the memory of the Colonial War from the private space of the family to the public space, as is the case with the three final statements by artists who have performed artistic work based in their condition as "children of the war". ${ }^{18}$ Insofar, these fragments help delineate an initial map of a "children of the war" discourse, a postmemorial discourse of the Colonial War, in the framework of which memory surfaces as a device to re-construct the history of the parents and to question it in new ways so as to make it one's own. Thus, it becomes clear that to inherit is not simply to receive something, but, above all, to select and extract, from what was received, a new narrative as a tool to affirm one's own contemporary existence. The question then arises: what is a "child of the war" after all?

A "child of the war" is someone for whom the war is but a representation, for the child has no first-hand knowledge of the events, nor is the child the author of the testimony, rather, he/she is the symbolic inheritor of an open sore from which to draw up a narrative - a possible testimony, an "adoptive testimony" in the sense posited by some theoreticians - constructed from fragments of family narratives made up of different types of discourse, snapshots, maps, letters, aerograms and other objects taken from the private domain, and also from fragments drawn from public narratives. Postmemory is fuelled to a great extent by images, grounded in the vast photo archive which participation in the war left in most Portuguese homes, and by the words written about it or which are uttered, at times without thought, making the war a matter that is not consciously spoken of. It is often activated by outside stimuli, as in the first case presented below; at other times it manifests itself through excess, that is,

18 Hugo Vieira da Silva, film director, Posto avançado de progresso, 2016; Paulo Faria, writer (2016); Ana Vidigal, visual artist, Penélope, installation (2001). All artists are children of veterans of the Colonial Wars in Africa (1961-1974). In the case of Ana Vidigal and Paulo Faria that relation is directly present in their artistic works, Hugo Vieira da Silva's work is an indirect reference. The film is based on the novel The Outpost of Progress, by Joseph Conrad. It is a reflection on the colonial situation and the reverse, both ironic and tragic, of the traditional adventure stories by European colonial authors. 
as a topic that is very present in family life, contrasting with an outside where public memory is lacking:

I hadn't expected that my father, who didn't have a fire-arm at all, who couldn't care less, who didn't speak about the war, who only spoke of mangoes and bananas and insects and storms, suddenly, upon hearing a noise [in the film Platoon]: "This is a shot of this or that, this is shot of I don't know what else; and napalm, this is what I saw ..." [...] And then we saw he really had war in him. ${ }^{19}$

And suddenly it appeared that war was only in the soldiers. And for me, in my own memory, it was nothing like that, because war was in my mother, in my mother's friend [...] It was something that was very much present! ${ }^{20}$

For many years, I thought it was quite odd that something that was discussed a lot in my family would not be spoken about. The colonial war seems to have been experienced by half a dozen people, it's not talked about. $^{21}$

Postmemory as a "memory" of subsequent generations is not coincident with a personal memory, it operates, in its "non-experiential" condition, as a memory of the "almost" or the "as if" as proposed by Rafaella di Castro with regard to third-generation Holocaust memory (Castro 2008). It is important to point out that, in the case of the Colonial War, the fragments supporting the construction of postmemory are most often supported by a family archive with which the child could come into close contact over the years in his/her own home, contrary to other cases such as the Holocaust, or the case of the children of missing persons in Latin American dictatorships or of the children of Europeans who came to Europe in the wake of decolonization processes leaving behind the family home and many other elements of identification,

19 "Eu não estava à espera que o meu pai que não tinha arma nenhuma, que andava sempre noutra, que não falava da guerra, que só falava de mangas e bananas e insectos, e tempestades, de repente ouvia um barulho [no filme Platoon]: 'isto é um tiro de não sei quê, isto é um tiro não sei que mais; e o napalm, isto é o que eu vi ...' [...] E aí percebia-se que havia ali guerra nele, de facto".

20 "E de repente parecia que a guerra estava só nos soldados. E para mim, na minha memória não era nada daquilo, porque a guerra estava na minha mãe, estava na amiga da minha mãe [...]. Era uma coisa muito presente!"

21 “... durante muitos anos eu pensei, durante muitos anos, que era muito engraçado que não se falasse uma coisa que é muito falada na minha família, e que não se falasse sobre isto! A guerra colonial é uma coisa que parece que foi vivida por meia dúzia de pessoas, não se fala". 
as a distant territory which will for ever remain only a product of the imagination. In these cases - among which the Holocaust builds the most extreme example - family fragmentation has been profound, the few objects that could perhaps be recovered, such as photographs or objects of personal use, becoming essential traces for a reconstruction of identity. In such situations, obsession with rememoration is well understandable, given the suspension of life brought about by the destruction of the archive.

In the case of the postmemory of the Colonial War, the archive - photographs, aerograms, different kinds of objects - and the protagonists themselves are present in the family home, which, quite frequently, allows to reconstruct a story in the absence of testimony by the father, be it because this testimony was not requested, or because, even when an explicit narrative on the side of the actor exists, silence on the most traumatic aspects of his experience remains the rule. In fact, many statements by ex-combatants stress that over the years there were no favourable conditions for the articulation of testimony, which is counterbalanced by the fact that the children often become weary of those testimonies being more or less always "the same stories of crocodiles and lions", rarely capable of diving into the most complex dimensions and, insofar, unable to satisfy the need to understand felt by the second generation. This situation also explains the silence, the turning away of the father in several moments, the explanations of the mother regarding dysfunctional behaviour by the father - "your father behaves like this because he was in the war" - and, above all, the amazement and distance of the children faced with a story which, although almost barely discerned in its entirety, strikes them as unbelievable.

Finally, all this helps to explain the long enduring presence in the second generation of the same absence of political questioning of the reasons leading to the involvement of the fathers in the conflict. In this regard, as is shown by many of the interviews we have been conducting, the TV documentary $A$ Guerra by Joaquim Furtado ${ }^{22}$ built a very relevant moment, not just for the triggering of a dialogue on the war within the families, but also of a first-time perception, for many former combatants, of the real political dimension of the conflict in which they let themselves be involved. In this respect, this was perhaps one of the most productive moments of the problematization of the war and of a political reading of the war, as, to this day, the most overwhelming and

22 The documentary was produced for the Portuguese National Television (RTP) and shown between 2007 and 2013 in four installments, totalling 42 episodes. 
suffocating inheritance of the dictatorship. ${ }^{23}$ When Primo Levi mentions the "duty of memory", it is not just the need to pass over testimony that is in question, but also a discussion of the reasons that made that testimony possible - it is a "duty" that reaches far beyond the private sphere to an inevitably political dimension. ${ }^{24}$ In the burgeoning field of memory studies, the perception has become consensual that the construction of memory has little to do with some kind of linear transmission, but, rather, builds a complex process where heterogeneous and ambivalent references are drawn upon in order to sustain a mode of relation to the past which is relevant to the contemporary position and location of the subject. Such processes do not occur simply at an individual level, they involve "communities of memory", which are represented in the first place by the family sphere, but imply many other levels, including the generational level (Pickering \& Keightley 2013). What the memory of the Colonial War we have studied in the research projects in reference shows is, precisely, that that war, although it is often incomprehensible and has no possible justification from the perspective of the "children", is clearly present in the horizon of this generation through mechanisms of recognition that are structured on the basis of a "mnemonic imagination", to use the concept theorized by Emily Keightley and Michael Pickering (2012). Such an imagination is capable of generating identity narratives both at the level of private memory, within the family sphere, and of public memory, in the latter case above all in the framework of art projects, showing how the discourse of the arts presents itself, also in the case of a Portuguese culture of memory, as the level of articulation that is needed to deal effectively with the complexity of the process.

23 Although the scale of both events is undoubtedly incommensurate, the huge impact of the TV series Holocaust (1979) on the memorialization of the Nazi genocide comes to mind as a comparable instance.

24 See Primo Levi (1997). If one thinks of the extreme, opposite case of the children of Nazi perpetrators, it becomes easier to conceptualize the burden of the situation of being the bearer of an identity that was not self-chosen, but, nonetheless, has to be carried, since, in the end, everything is in a name, the name that forces each child to come to terms with a legacy in some way handed over to him/her either by a victim or a perpetrator. In the extensive interviews conducted by the American journalist Gerald L. Posner, Hitler's Children ... (1991), this question is widely thematized (including the journalist's own difficulty of identifying the "children"). This was a question that in Germany, in the wake of the students' movement at the end of the 60s, gave rise to the so-called "father literature", of which Bernward Vesper's autobiographic novel-essay Die Reise [The Journey] (posthumously published in 1977) is a prominent example. 
In the 150 interviews we carried out with children, born between 1960-1985, of former combatants, as well as of a small group of non-combatants, it became clear that the traumatic impact of the war was projected especially within the family, and not so much at the community level. Generally, for the majority of the children interviewed, the war was something not often spoken about, as well as being little questioned beyond the family circle. In other words, it rarely was a political issue that would leave the family domain and enter the public realm. It is not a foundational identity narrative (as it is for the former soldier). Taking up the mantle of being "a child of the war" is first and foremost a family affair, which may later find, or not find, a space in the public arena.

We have identified three groups whose identities were particularly marked by the option of the father in regard to the Colonial War. A first group is composed of children of men who came back from the war with physical disability or psychological damage (the latter not being, quite often, duly clinically acknowledged); a second group is composed of children of men who took the option of deserting the army so as not to be obliged to go to war; finally, a third group, of those whose fathers have returned home apparently with no visible damage. Of particular interest were those children who - mostly within this third group and in most cases on the basis of their socialization within the family - engaged in creative activities and chose to project themselves imaginatively on modes of experience not their own out of the puzzle of images and histories building up their inheritance from the Colonial War.

The first group are mostly the children of men suffering from posttraumatic stress disorder, who had since childhood to cope with and try to understand their father's condition. Today, as our results show, they are clearly more vulnerable to psychological and emotional problems than children who grew up in "normal" contexts. As one of our interviewees said, they are in the position of living in a war where they have never been, since they have been exposed at home since childhood to terrible situations connected to the experience of war. The legacy of a traumatic past, deeply affecting not just the father, but also quite often an emotionally exhausted mother, extends in this way to the children, raised in an atmosphere they are seldom able to understand and who react in two different ways that are apparently opposed, but, as a rule, are concomitant: on the one hand, avoidance of the problem, which is absent from conversation out of fear that the memory of the war may be triggered; on the other hand, a deep will to understand what the Colonial War really was, so that the legacy they carry may have some meaning. The conclusion is, as a rule, unsatisfactory: the perception of the huge equivocation in which the father 
was involved, generating, on the one hand, revolt and the victimization of the father and, on the other hand, an increased amazement and questioning of the silence in the public sphere on an event, the Colonial War, always so much present within their own family.

Ever since I remember my home, I always remember the war, it was always always, always present in that house. Always, always. I'd go out and think: and the others? Where are they? Was no one there? Did the -parents of the others not go to war? ${ }^{25}$

What was all the suffering for? [...] What for? [...] Whenever there is a documentary on television, I try not to miss it. I need to try to understand. I think there are still big problems, a lot of problems, that the people who were there had, and that isn't made public, I think. [...] I suppose no one can imagine what the families go through, by having someone like that at home. And no one thinks about it, no one speaks. ${ }^{26}$

The second group are the children of deserters, who were often born abroad and whose childhood was marked by their fathers' political choices. This group is clearly more politicized. Generally, they cope well with a certain degree of animosity within Portuguese society towards their fathers' position, feeling a certain amount of pride in their fathers' rejection of the war. They see the Colonial War as something utterly incomprehensible and anachronistic. Within this group, it becomes particularly clear to what extent the memory of the Colonial War, as the memory of a kind of national politics based on the colonial oppression of other peoples in the name of a mythical imperial past does not resist any type of explanation or justification when questioned from the perspective of the second generation and, thus, may be the foundation of a political ethos for future generations regarding the illegitimacy of violence and domination.

25 "Desde que eu me lembro de mim em casa, sempre me lembro, da guerra, naquela casa, esteve sempre, sempre, sempre presente. Sempre, sempre. E saía de casa e pensava: e os outros, onde estão, ninguém lá esteve? Os pais dos outros não foram à guerra?"

26 "Por que é que foi todo este sofrimento? [...] Para quê? [...] Sempre que há algum documentário na televisão, eu tento não perder. Preciso de tentar perceber. Ainda há grandes problemas ..., muitos problemas, que as pessoas que lá andaram tiveram, e isso não é trazido para a praça pública, penso eu. [...] Acho que ninguém imagina o que as famílias passam, ter uma pessoa dessas em casa. E ninguém imagina, ninguém fala?" 
Maybe at home, we'd talk more about the dictatorship. I heard more about it, about Salazar, the political police, and all that. Meanwhile, by the way, wait, after all, there is a Colonial War. There was a time when I was amazed, I do not know at what age, probably in pre-adolescence, I do not know ... I was amazed ... ah! I was even shocked. We are the same, we were also occupying other territories, we were also colonialist. ${ }^{27}$

For different reasons, these two groups show most starkly that the memory of the Colonial War, once questioned from the second generation onwards, cannot indeed be explained or justified. In this regard, the war becomes "unfinished business" and, thus, a postmemory of the Colonial War represents, above all else, the refusal to put a full stop after it.

The children of the third group in reference are those who are mainly turning the postmemory of the Colonial War into something that is gaining visibility and increasingly occupying the public space. Through an authorial gesture, they are proving able to establish a public contract with what could be a possible dialogue with previous generations and, at the same time, a confrontation with a national past brought into interrogation from the point of view of a critique of violence.

\section{Postmemorial Art}

The artistic and cultural production of post-memory connected with the Colonial War is an ongoing phenomenon which is clearly expanding. In general, we can say that literature, cinema, the visual arts, and the performing arts are the initial and privileged artistic territories for this questioning. It is in these areas that we find the first records, whose initial reception, particularly in literature and the visual arts, was far from being conscious of the import of the theme put forward by these works. We emphasize in literature, already in 1992, Daqui a nada by Rodrigues Guedes de Carvalho (2005), which has two characteristics that will mark the post-memorial literature of the Colonial War. In formal terms, a profound influence by the writing of António Lobo Antunes,

27 "Se calhar em casa ouvi falar mais da ditadura. Ouvi falar mais nisso ... no Salazar, nas PIDEs e isso tudo. Entretanto, por acréscimo, esperem aí, afinal há uma Guerra Colonial. Houve uma altura que fiquei admirado não sei com que idade, deve ter sido na pré-adolescência, não sei ... Fiquei admirado ... ah! Fiquei até chocado. Nós também somos, também estivemos a ocupar outros territórios, também fomos colonialistas". 
a leading author of the generation of witnessing. In terms of content, a (non)dialogue with the father figure. This is the aspect that somehow unifies the children's novels of the Colonial War, curiously all of them of male authorship a dialogue with the father figure about the losses that often turns it into the figure of the homeland, Portuguese colonialism in Africa or war, reminiscent as such of the first-generation novel by Helder Macedo, Partes de África (1991). This is the meaning of works such as Impressão digital ou a tipografia de uma existência indizivel by Norberto Vale Cardoso (2005), the son of an excombatant who brought the war home, As sete estradinhas de Catete, by Paulo Bandeira Faria (2007), the first novel in which the Colonial War is seen and questioned by a child, O anjo branco, by José Rodrigues do Santos (2010), or the recent and impressive Estranha guerra de uso comum, by Paulo Faria (2016), which is clearly a more complex book, composed of testimonies by his father's companions, posthumously approached by the son-author, and posthumous letters to the father of an heir in mourning.

The visual image is deeply connected to the construction of post-memory family and propaganda films, photographs, real and imaginary images, drawings and other graphic materials. Letters were especially important, with their shapes, colours, stamps, all in addition to the traditional narrative content. Perhaps for that reason, the work of the visual arts had its development in the early 2000s drawing extensively on the archives, with the works of Ana Vidigal, VOID and Penélope, and Ultramar, by Miguel Palma. For these artists, as well as for the subsequent ones, the grammar of colonial questioning written by Ângela Ferreira in her works, ${ }^{28}$ as well as Clara Menéres Jaz Morto e Arrefece (quoting a line from the poem O Menino de Sua Mãe by Fernando Pessoa), exhibited in 1973 at the National Fine Arts Society has proved quite relevant. Menéres' work shows the body of a dead soldier, in real-life size, therefore hyperrealistic, and is still today one of the strongest critical approaches to the Colonial War, to which Ana Vidigal would not have been indifferent. ${ }^{29}$ We will concentrate our attention on VOID and above all Penelope by Ana Vidigal, a daring work which all the others, especially those by a younger generation, emulate, without, however, reaching the level of the deep questioning here initiated.

28 See Maison Tropicale, 2007; Casa de Colonos Abandonada, 2007 among others, <https://www.artsy.net/artist/angela-ferreira/works?page=1\&sort=-partner_updated>, acessed 31 May, 2018.

29 Cf. a photograph of the sculpture at <https://pt.wikipedia.org/wiki/Ficheiro:Clara_ Men\%C3\%A9res,_Jaz_morto_e_arrefece_o_menino_de_sua_m\%C3\%A3e,_1973.jpg>, acessed 31 May, 2018. 
Ana Vidigal is a Portuguese visual artist who would seem to have no connection with Africa, had her father not been one of the many Portuguese metropolitan youths mobilized to Angola for the Colonial War in the 1960s. Her early years were marked by his absence because of the war, by her mother's loneliness and the arrival of letters from Africa. Ana Vidigal's VOID is an installation representing her children's room covered with the photos and aerograms of her father; Penélope, the bedspread she dedicated to her mother, covered, in the words of the artist, with the letters with each the latter went to bed during the two years her husband spent in in Guinea-Bissau over the two years of her father's commission. ${ }^{30}$ Penélope is in fact a quilt made up of the airmail letters Vidigal's father sent to her mother. These were the letters with which, as a child, she saw her mother go to bed over the two years of her father's commission. A private, family memory informs Penélope. But Penélope is also a work of art and the author's public gesture speaks to us of the men who went to war, and of the women who waited for their husbands, who might not return. This scene, like the name Penélope itself, is freighted with a long history. Looking at this quilt, we imagine how real it was for so many Portuguese women as an artefact of shelter and warmth and we wonder which mattered most to them: the words on the paper or the materiality of the missing partner's body projected onto the paper. Today, perhaps Penélope is no more than the memory of cold and loneliness, and we believe that the Ulysses of this story also has an equivalent quilt yet to be made. Penélope is a beautiful gift from a daughter to her mother, made of attention, pain and compassion, but it is also a gesture of authorship, which inscribes in the public space that which until then was only a private family memory. And so Penélope is also the record of an absence projected onto the children of the Colonial Wars.

But why does Ana Vidigal reserve a theme as structurally public as the Colonial War for such an absolutely private domain as the interior of the house, the bed of her parents and the correspondence they exchanged during the war? We think that the artistic developments that followed in the works of Nuno Nunes-Ferreira or Daniel Barroca contain the answer by maintaining this almost intimate character of reworking their father's war photographs and materials, in fact a disturbing intrusion into the parent's war photographs as is the case with Daniel Barroca, from Mapa de cumplicidades, of 2011, based on the photo album of the artist's father, to Circular Body, of 2015, in which

30 Both works were on display at the important individual exhibition celebrating 30 years of artistic career at the Calouste Gulbenkian Foundation (Menina Limpa, Menina Suja, Centro de Arte Moderna, July 23 to September 26 2010), under the curatorship of Isabel Carlos. 
he reelaborates his work on the ground of archives which were hidden in the same album. Daniel Barroca's work is above all a demand for the truth about the Colonial War in which his father was involved. A quest in which everyone loses his innocence or feels naked in the face of any hypothesis of possible explanation. To this extent this work constitutes not only a post-testimony on the Colonial War, but also a hypothesis of individual and collective post-catharsis on the intimate ghosts of war.

In the field of the cinema a great variety is present. In an area of original feminine authorship, Margarida Cardoso's systematic work clearly highlights an innovative way of approaching the theme. A Costa dos Murmúrios, by Margarida Cardoso (2004) is a second-generation representation - her movie on a first-generation representation, the novel The Coast of Whispers, by Lídia Jorge, a novelist, but also a woman who accompanied her husband on mission in the Colonial War in Mozambique; this will also be the form adopted by Luísa Marinho in the documentary Poeticamente exausto, verticalmente só (2007), a hommage to the poet João Bação Leal, killed in action in Mozambique and author of one of the first books denouncing the Colonial War, Cartas e Poemas de José Bação Leal, published posthumously in 1971; Ivo Ferreira, Cartas de guerra (2016), is also much more than an adaptation of the letters by António Lobo Antunes to his wife by a second generation director. The new proposals, by José Miguel Ribeiro with the first animated movie Estilhaços (2015), which won prizes in several festivals, and the movies by Filipa César, based on archive research on the opposite side of the struggle, with Conakry (2012) and the recent Spell Reel (2017), launch other ways of dealing with the subject, either from the point of view of the image and the grammar that underlies them, or from the point of view of those who cast their eyes. In Estilhaços the Colonial War and its consequences are analyzed from the point of view of the son who successively questions a father about the war stories that came to him. But in the movie, the father never responds. On the other hand, Filipe César's Conakry features the other side of this war, the Liberation War or the struggle for independence in Guinea-Bissau filmed by Sana N'hada. ${ }^{31}$ In Filipa César's Conakry an Afrodescendant woman, the Portuguese artist Grada Kilomba, adds sound to the archive film and thus questioning the images. Grada Kilomba grew up in Lisbon, where her family came following decolonization. When she sees an

31 Sana na N`Hada, Josefina Crato, José Bolama Cabumba and Flora Gomes are Guinean filmmakers. In 1967 Amílcar Cabral sent them to the Instituto Cubano de Arte e Indústrias Cinematográficas where they worked with Santiago Álvarez. In 1972 they returned to Guinea-Bissau. Between 1972 to 1980 they shot the films of Guinea-Bissau's liberation movement during the struggle for independence and the first years of the new nation. 
archive film about the movements of the liberation struggle in Guinea Bissau, very much focused on the figure of Amilcar Cabral, she discovers a story that has never been told, neither at home nor at school. A story that would have allowed her to understand her origins and her crossing over, a story from the other side of the war and that she felt she had been deprived of. This is one of the themes of Conakry, by Filipa César, who rewrites stories on the basis of films by the Guinean director Sana N 'Hada.

In the performing arts, the reenactment of war for the next generations contemplates both sides of the war, as we see in the trilogy by Hotel Europa André Amálio. In three pieces around the Colonial Wars and the liberation struggles and on the return movements of decolonization - Portugal is not a small country (2015), Pass-Port, Liberation (2017). The last play enacts the misconceptions of a double or triple name war. In the path of documentary theater we may also mention the initial work Ignara \# Colonial War: doing the housework (2008), by Teatro Mosca, a play built up of fragments of public and private narratives of the Colonial War staged and acted by children of the war, and also dealing with the topic, but not making it the central theme, of Joana Craveiro's extraordinary theatrical work at the Teatro do Vestido.

The authors of these works construct fictions, in the form of novels, poems, visual art pieces or films, set in Africa or thematizing the return from Africa, based on times, characters and spaces relating to the period of the Colonial War. These are scenes, experiences, love relationships and dialogues they have not experienced, but have probably heard of, because they were part of the living experience of their parents' generation. Sometimes, they dedicate their work to their parents, thus trying to establish a bridge between the generation that lived through the Colonial War and the subsequent generation. ${ }^{32}$ So far, both the artistic, public work carried out by the "children of the war" and many of the interviews we have conducted present multiple questions that could only be raised by a second generation, without falling, like their parents' generation, into the abyss of guilt or traumatic silence. In these discourses, the reasons for so many existences haunted by the ghosts of Africa, by abandonment and incomprehension, start to be inquired into, but also the first more elaborate and politicized reflections on what the Colonial War really was and, above all, on its contemporary extensions into Portuguese society are starting to surface.

32 "Para os meus pais, que viveram este livro para além das palavras [For my parents, who lived this book beyond words], dedication by Rodrigo Guedes de Carvalho, Daqui a nada; Para os meus pais [For my parents], dedication by José Rodrigues dos Santos, $O$ anjo branco; Este é o espaço para a impressão digital dos meus pais" [This is the space for the fingerprints of my parents], dedication by Norberto do Vale Cardoso (2005). 
However, the underlying biographic framework leads to avoiding confrontation, tending instead, towards a possible reconciliation marked by recognition and compassion, generated by a pact of emotional sharing, an intergenerational pact extending increasingly from the family into the public sphere.

\section{$4 \quad$ Concluding Remarks: A Democracy with Memory}

The reflection we have been undertaking on the postmemory of the Colonial War has shown that, in a context where the belief still prevails that the legitimacy of representation belongs solely to the bearers of its direct experience, the constellation testimony-trauma-postmemory-representation can operate as a pivotal tool with which to re-think what the Portuguese Colonial War was and which imprint - visible or invisible - it left on the generations that followed. Clearly, there is still no consensual narrative regarding both the Colonial War and its enduring impact in Portuguese society - the topic is bound to remain controversial and divisive for generations to come. In its outermost manifestations, however, postmemory generates a new memory which resignifies the losses and voids of the past - if only by asking for an explanation creating different possibilities in the ethics of representation of the war. We are thus witnessing the building up of a multifaceted and multidirectional discourse network which, while nourishing itself from the knowledge of the past and the questioning of the past, is firmly grounded in a dimension of contemporaneity.

Well beyond the direct protagonists and their descendants, the transgenerational building up of an increasingly politicized public memory uncovers spaces of opportunity to rethink the Colonial War, creating the possibility of a collective definition of a responsibility towards the past that may offer, if not a guarantee, at least the prospect of the consolidation of a democracy with memory. At the same time, the revisitation of Portuguese colonialism forced upon the second generation by the confrontation with the painful experiences of their parents, although it is undertaken under perspectives that may be quite different among themselves, cannot but put in question the myth of peaceful coexistence still very much present in dominant Portuguese discourse concerning the country's colonial past.

Thus, nostalgic, ideological versions of a common Lusophone space increasingly give way to more complex, critical, implicitly or explicitly postcolonial approaches, which may potentially provide a relevant contribution towards the building up of a relationship between Portugal and its former African colonies which is not grounded in the erasure of the past. In this respect, there is, 
however, still a long way to go, building from historically grounded realities which are called in this issue lusotopy -, far away from lusophone, if not lusotropicalist myths.

\section{References}

Antunes, A. Lobo 1989, Fado Alexandrino, Lisboa, Dom Quixote.

Antunes, A. Lobo 2006, "07890263 ORH+", in Terceiro livro de crónicas, Lisboa, Dom Quixote: 111-114.

Blanchard, P. et al. 2005, La Fracture coloniale. La société française au prisme de I'héritage colonial, Paris, La Découverte.

Cardoso, N. Vale 2005, Impressão digital ou a tipografia de uma existência indizível, Lisboa, Roma Editora.

Carvalho, R. Guedes de 2005, Daqui a nada, Lisboa, Dom Quixote.

Castro, R. Di 2008, Testimoni del non-provato. Ricordare, pensare, immaginare la Shoah nella terza generazione, Roma, Carocci.

Cru, J. N. 1929, Témoins: essai d'analyse et de critique des souvenirs de combattants édités en français de 1915 à 1928, Paris, Les Étincelles.

Dubiel, H. 2003, "The Remembrance of the Holocaust as a Catalyst for a Transnational Ethic", New German Critique, 90: 59-70.

Faria, P. 2016, Estranha guerra de uso comum, Lisboa, Ítaca.

Faria, P. Bandeira 2007, As sete estradinhas de Catete, Porto, Quidnovi.

Halbwachs, M. 1994 [1925], Les cadres sociaux de la mémoire, Paris, Albin Michel.

Halbwachs, M. 1997 [1950], La mémoire collective, Paris, Albin Michel.

Hartman, G. 2006, "The Humanities of Testimony: An Introduction", Poetics Today, 27

(2): 249-260.

Hirsch, M. 1997, Family frames: photography, narrative, and postmemory, Cambridge, Harvard University Press.

Hirsch, M. 2008, "The Generation of Postmemory", Poetics Today, 29 (1): 103-128.

Keightley, E. \& Pickering, M. 2012, The Mnemonic Imagination: Remembering as Creative Practice, New York, Palgrave Macmillan.

Kertész, I. 2001, “Who Owns Auschwitz?", The Yale Journal of Criticism, 14 (1): 267-272.

LaCapra, D. 1998, History and Memory after Auschwitz, Ithaca, Cornell University Press.

Levi, P. 1997, O dever de memória, Porto, Civilização.

Levy, D. \& Sznaider, N. 2002, "Memory Unbound. The Holocaust and the Formation of

Cosmopolitan Memory", European Journal of Social Theory, 5 (1): 87-106.

Macedo H. 1991, Partes de África, Lisboa, Presença.

Pickering, M. \& Keightley, E. 2013, "Communities of Memory and the Problem of

Transmission", European Journal of Cultural Studies, 16 (1): 115-31. 
Posner, G. L. 1991, Hitler's children: sons and daughters of leaders of the third reich talk about their fathers and themselves, New York, Random House.

Rand, N. 1994, The Shell and the kernel: renewals of psychoanalysis. vol. 1, Chicago, University of Chicago Press.

Ribeiro, A. Sousa 2010, Memória, identidade e representação: Os limites da teoria e a construção do testemunho, Revista Crítica de Ciências Sociais, 88: 9-21.

Ribeiro, M. Calafate 2004, Uma história de regressos. Império, guerra colonial e póscolonialismo, Porto, Afrontamento.

Rodrigues, I. 2017, Espectros de Batepá. Memória, Identidade e Diferença Sexual nas Representações Literárias do "Massacre de 1953» em São Tomé e Príncipe, Centro de Estudos Sociais e Faculdade de Economia da Universidade de Coimbra, PhD thesis.

Santos, J. Rodrigues dos 2010, O anjo branco, Lisboa, Gradiva.

Sarlo, B. 2007, Tempo Passado. Cultura da memória e guinada subjetiva, São Paulo/Belo Horizonte, Companhia das Letras/ Editora da UFMG: 90-113.

Silva, H. Vieira da 2016, film director, Posto avançado de progresso.

Stora, B. 1999, Le Transfert d'une mémoire. De l'Algérie française au racisme anti-arabe, Paris, La Découverte.

Vesper, B. 1977, Die Reise. Romanessay, Frankfurt am Main, März bei Zweitausendeins.

Vidigal, A. 2010, Fui educada para ser uma menina limpinha, interview by Anabela Mota Ribeiro, Pública, July 9.

Wieviorka, A. 2002, L'Ère du témoin, Paris, Hachette.

Young, J. E. 2000, At memory's edge: after-images of the holocaust in contemporary art and architecture, New Haven, Yale University Press.

This article was prepared for the project MEMOIRS - Children of Empires and European Postmemories, funded by the European Research Council (ERC) under the European Union's Horizon 2020 research and innovation programme (grant agreement No. 648624) and coordinated by Margarida Calafate Ribeiro. The article also draws upon the project Children of the Colonial Wars: Postmemory and Representations, financed by the National Agency for Science and Technology (Fundação para a Ciência e Tecnologia) and the Ministry of National Defense (Ministério da Defesa Nacional), 2007-2011. The research team, led by Margarida Calafate Ribeiro, included António Sousa Ribeiro (CES), Roberto Vecchi (University of Bologna), Luísa Sales (Coimbra Military Hospital), Rui Mota Cardoso and Ivone Castro Vale (Medical School of the University of Porto), Aida Dias, Hélia Santos, Luciana Silva and Mónica Silva (CES). (<www.ces.uc.pt/projectos/filhosdaguerracolonial/>). Both projects were guided by the desire to understand the following generation's possible narratives of their diverse colonial parents' experience at two connected levels: as a personal and collective identity narrative and a mark of increased vulnerability to trauma as an intergenerational phenomenon. 